\title{
Design of Comb Crack Resistant Milling Inserts: A Comparison of Stresses, Crack Propagation, and Deformation Behavior between $\operatorname{Ti}(\mathrm{C}, \mathrm{N}) / \alpha-\mathrm{Al}_{2} \mathrm{O}_{3}$ and $\mathrm{Zr}(\mathrm{C}, \mathrm{N}) / \alpha-\mathrm{Al}_{2} \mathrm{O}_{3} \mathrm{CVD}$ Coatings
}

\author{
Maiara Moreno ${ }^{1}$, Idriss El Azhari ${ }^{2, *}$, Daniel Apel ${ }^{3}$, Matthias Meixner ${ }^{3}$, Wei Wan ${ }^{4}$, Haroldo Pinto ${ }^{1}$ (D, \\ Flavio Soldera ${ }^{2}$ (D), Frank Mücklich ${ }^{2}$ and José García ${ }^{4, *}$ \\ 1 Department of Materials Engineering, University of São Paulo, 13563-120 São Carlos, SP, Brazil; \\ morenomaiara95@gmail.com (M.M.); haroldo@sc.usp.br (H.P.) \\ 2 Chair of Functional Materials, Department of Materials Science, Saarland University, Campus D3.3, \\ D-66123 Saarbrücken, Germany; f.soldera@matsci.uni-sb.de (F.S.); muecke@matsci.uni-sb.de (F.M.) \\ 3 Abteilung Mikrostruktur-und Eigenspannungsanalyse, Helmholtz-Zentrum Berlin für Materialien und \\ Energie GmbH, D-12489 Berlin, Germany; daniel.apel@helmholtz-berlin.de (D.A.); \\ matthias.meixner@helmholtz-berlin.de (M.M.) \\ 4 AB Sandvik Coromant, R\&D Material and Processes, SE-12680 Stockholm, Sweden; wei.wan@sandvik.com \\ * Correspondence: idriss.elazhari@uni-saarland.de (I.E.A.); jose.garcia@sandvik.com (J.G.)
}

check for updates

Citation: Moreno, M.; El Azhari, I.; Apel, D.; Meixner, M.; Wan, W.; Pinto, H.; Soldera, F.; Mücklich, F.; García, J. Design of Comb Crack Resistant Milling Inserts: A Comparison of Stresses, Crack Propagation, and Deformation Behavior between $\mathrm{Ti}(\mathrm{C}, \mathrm{N}) / \alpha-\mathrm{Al}_{2} \mathrm{O}_{3}$ and $\mathrm{Zr}(\mathrm{C}, \mathrm{N}) / \alpha-\mathrm{Al}_{2} \mathrm{O}_{3}$ CVD Coatings. Crystals 2021, 11, 493. https://doi.org/10.3390/ cryst11050493

Academic Editor: Jakub Hajkowski

Received: 31 March 2021

Accepted: 25 April 2021

Published: 28 April 2021

Publisher's Note: MDPI stays neutral with regard to jurisdictional claims in published maps and institutional affiliations.

Copyright: (c) 2021 by the authors. Licensee MDPI, Basel, Switzerland. This article is an open access article distributed under the terms and conditions of the Creative Commons Attribution (CC BY) license (https:// creativecommons.org/licenses/by/ $4.0 /)$.
Abstract: Investigations on comb crack resistance of milling inserts coated with chemical vapor deposition (CVD) $\mathrm{Ti}(\mathrm{C}, \mathrm{N}) / \alpha-\mathrm{Al}_{2} \mathrm{O}_{3}$ and $\mathrm{Zr}(\mathrm{C}, \mathrm{N}) / \alpha-\mathrm{Al}_{2} \mathrm{O}_{3}$ showed a distinct wear evolution in both systems. Wear studies revealed that the appearance of comb cracks is connected to the initial CVD cooling crack network. Micropillar compression tests indicated a brittle intergranular fracture mechanism for the $\mathrm{Ti}(\mathrm{C}, \mathrm{N})$ layer and a transgranular fracture accompanied with signs of plastic deformation for the $\mathrm{Zr}(\mathrm{C}, \mathrm{N})$ coating. Additionally, for the $\mathrm{Zr}(\mathrm{C}, \mathrm{N})$ based system, a compressive stress condition in the temperature range of interest $\left(200-600^{\circ} \mathrm{C}\right)$ was determined by in-situ synchrotron X-ray diffraction. The set of residual compressive stresses together with the ability of the $\operatorname{Zr}(\mathrm{C}, \mathrm{N})$ layer to deform plastically are key features that explain the enhanced resistance to comb crack wear of the $\mathrm{Zr}(\mathrm{C}, \mathrm{N})$ based system in milling of cast iron.

Keywords: milling inserts; comb crack wear; polycrystalline CVD coatings; in-situ synchrotron X-ray diffraction; micro-mechanics; residual stress engineering

\section{Introduction}

Cemented carbides coated with wear resistant layers deposited either by physical or chemical vapor deposition (PVD or CVD) are predominant cost-effective tools for machining of automotive parts and aerospace components [1]. Machining involves processes such as turning or milling, where interrupted cutting condition causes faster degradation of the cutting edge and reduced tool life. It is known that the main wear mechanism that reduces the performance of milling inserts is the formation of thermo-mechanical cracks, also known as comb cracks [2,3]. Tool life of cutting inserts can be enhanced by deposition of tailored wear resistant layers. The use of CVD coated inserts has the advantage of versatility in coating thickness and the production of multilayer systems that combine resistance against wear, chemical reactions, oxidation, and thermal load. The most common system used is the combination of $\mathrm{Ti}(\mathrm{C}, \mathrm{N})$ as the wear resistant layer and $\mathrm{Al}_{2} \mathrm{O}_{3}$ as the chemical and thermal barrier outer layer [4]. However, a main drawback of CVD coating systems is the presence of a network of microcracks formed during the cooling step of the CVD process after deposition at high temperature [5]. This network of cracks stems from the difference in coefficient of thermal expansion (CTE) between the cemented carbide and the coating layers, which generates tensile stresses above the yield strength of the films, leading to crack formation and relaxation of stresses [6]. The cutting tool industry has developed 
post-treatment processes to close pre-cracks and to introduce high compressive stresses in the CVD coatings, i.e., blasting/peening, in which the surface of the as-coated inserts is bombarded with different particles at high pressure [7-9]. The introduction of compressive stresses delays the opening of the initial microcrack network and the propagation of such microcracks as well as the formation of new cracks during the oscillating conditions of stress and temperature in the milling process. The study and understanding of residual and thermal stresses are therefore a key feature to control the crack formation and hence improve the tool life of CVD coated milling inserts [10-12]. In a recent work, the authors have investigated the thermal cycling behavior of $\mathrm{Ti}(\mathrm{C}, \mathrm{N}) / \alpha-\mathrm{Al}_{2} \mathrm{O}_{3}$ coating systems in both as-coated and top-blasted conditions [13]. Main observations were the reversible correlation of stresses with the temperature cycles, the introduction of compressive stresses in the $\alpha-\mathrm{Al}_{2} \mathrm{O}_{3}$ layer by top-blasting associated with a high density of defects; and the relaxation of such induced compressive stresses by annihilation of defects in a thermally activated process. Another conclusion was that the use of CVD layers with a low CTE -such as $\mathrm{Zr}(\mathrm{C}, \mathrm{N})$ or $\mathrm{Hf}(\mathrm{C}, \mathrm{N})$ - would be favorable to withstand crack propagation.

To continue this residual stress engineering approach, the behavior of the $\operatorname{Ti}(\mathrm{C}, \mathrm{N}) / \alpha-$ $\mathrm{Al}_{2} \mathrm{O}_{3}$ and $\mathrm{Zr}(\mathrm{C}, \mathrm{N}) / \alpha-\mathrm{Al}_{2} \mathrm{O}_{3}$ systems is compared in terms of residual stresses, crack formation/propagation, micro-deformation and comb crack resistance for milling of cast iron. Investigations are conducted by a combination of several techniques, including in-situ synchrotron X-ray diffraction and micropillar compression. The aim is to link the response of the coating towards thermal and mechanical loads to the wear evolution in real machining conditions for further understanding of the mechanisms that govern comb crack wear in CVD coated milling inserts.

\section{Materials and Methods}

Coating systems $\mathrm{Ti}(\mathrm{C}, \mathrm{N}) / \alpha-\mathrm{Al}_{2} \mathrm{O}_{3}$ and $\mathrm{Zr}(\mathrm{C}, \mathrm{N}) / \alpha-\mathrm{Al}_{2} \mathrm{O}_{3}$ were deposited on WC-6 wt.\% Co substrates using an industrial hot-wall CVD reactor. In both coating systems, a thin TiN starting layer of $0.3 \mu \mathrm{m}$ was deposited between the cemented carbide substrate and the wear resistant carbonitride layer followed by a bonding transition layer $\mathrm{Ti}(\mathrm{C}, \mathrm{N}, \mathrm{O})$ and the $\alpha-\mathrm{Al}_{2} \mathrm{O}_{3}$ layer (Figure 1). The thickness and properties of the $\mathrm{Zr}(\mathrm{C}, \mathrm{N}), \mathrm{Ti}(\mathrm{C}, \mathrm{N})$ and $\alpha-\mathrm{Al}_{2} \mathrm{O}_{3}$ layers is given in Table 1 . Coated samples were subjected to top-blasting process with alumina particles using a $250 \mu \mathrm{m}$ mesh at 2 bars for $60 \mathrm{~s}$. Microstructural changes induced by blasting were observed by transmission electron microscope (TEM).
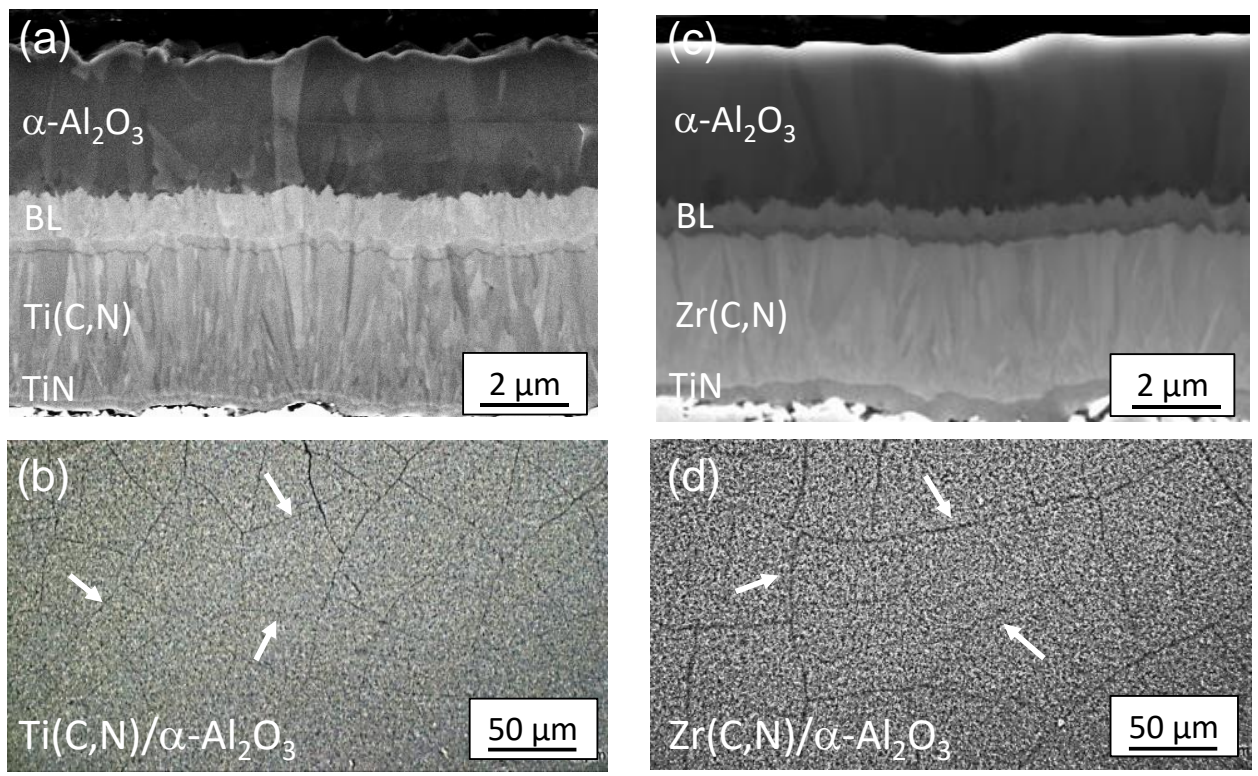

Figure 1. (a,c) SEM images of as-coated systems investigated (polished cross-sections) (b,d) LOM top-view images for the as-coated condition showing $\alpha-\mathrm{Al}_{2} \mathrm{O}_{3}$ outer layer. White arrows indicate CVD crack network. 
Table 1. Elastic and thermal properties for the substrate and coating materials [13-16].

\begin{tabular}{ccccc}
\hline $\begin{array}{c}\text { Substrate/ } \\
\text { Coating Layer }\end{array}$ & $\begin{array}{c}\text { E-Module } \\
{[\mathrm{GPa}]}\end{array}$ & $\begin{array}{c}\text { Poisson } \\
\text { Coefficient } v\end{array}$ & $\begin{array}{c}\text { Average CTE } \\
\left(\mathbf{2 0 - 8 0 0}{ }^{\circ} \mathbf{C}\right)\left[\mathbf{1 0}^{-6} \mathbf{6} \mathbf{K}\right]\end{array}$ & $\begin{array}{c}\text { Film Thickness } \\
{[\boldsymbol{\mu m}]}\end{array}$ \\
\hline $\mathrm{WC}-\mathrm{Co}$ & $620 \pm 20$ & 0.22 & 5.7 & - \\
$\alpha-\mathrm{Al}_{2} \mathrm{O}_{3}$ & $440 \pm 20$ & 0.22 & a: $8.4 / \mathrm{c}: 9.0$ & 3.0 \\
$\mathrm{Ti}(\mathrm{C}, \mathrm{N})$ & $450 \pm 20$ & 0.19 & 9.0 & 4.0 \\
$\mathrm{Zr}(\mathrm{C}, \mathrm{N})$ & $405 \pm 20$ & 0.177 & 7.65 & 4.5 \\
\hline
\end{tabular}

Another set of single layered samples is produced having only the carbonitride layer as an outer layer, i.e., $\operatorname{Ti}(\mathrm{C}, \mathrm{N})(5.0 \pm 0.2 \mu \mathrm{m})$ and $\operatorname{Zr}(\mathrm{C}, \mathrm{N})(5.0 \pm 0.2 \mu \mathrm{m})$ without the bonding layer $\mathrm{Ti}(\mathrm{C}, \mathrm{N}, \mathrm{O})$ and $\alpha-\mathrm{Al}_{2} \mathrm{O}_{3}$ layer.

The resistance to thermo-mechanical cracks was tested in wet milling of cast iron on a test block of grey cast iron SS0125 with dimensions $305 \times 120 \times 50 \mathrm{~mm}^{3}$. The test block was face-milled with the cutter moving from the right side to the left side of the test block. The cutting parameters were: $\mathrm{vc}=220 \mathrm{~m} / \mathrm{min}, \mathrm{fz}=0.25 \mathrm{~mm}$, ae $=60 \mathrm{~mm}$, ap $=3.0 \mathrm{~mm}$, using an industrial cooling emulsion of $8 \%$. The test was stopped at certain milled surfaces to track the wear evolution (comb cracks, crater, and flank wear) by light optical microscopy (LOM) and scanning electron microscopy (SEM) imaging. The inserts were analyzed after end tool life in polished cross-sections. At least 8 inserts were analyzed for each condition.

Residual and thermal stresses were analyzed in-situ at room temperature and during thermal cycling conditions using synchrotron X-ray diffraction at the Material Science Beamline EDDI (Energy-Dispersive Diffraction) at the storage ring BESSY in Berlin, Germany [17]. The inserts were heated in an Anton-Paar furnace under flowing Ar. A thermocouple was mounted on the inserts to track the temperature. After initial measurement at room temperature $\left(\mathrm{RT}=25^{\circ} \mathrm{C}\right)$ the samples were heated/cooled in steps of $200^{\circ} \mathrm{C}$ up to $800{ }^{\circ} \mathrm{C}$ to determine thermal stresses. The heating/cooling cycles (RT- $800{ }^{\circ} \mathrm{C}-\mathrm{RT}$ ) were carried out at temperature steps of $200^{\circ} \mathrm{C}$. After initial measurement of residual stresses at RT, the samples were heated until the desired temperature to determine the thermal stresses. Each measurement at the defined temperature step lasted around 8 to $10 \mathrm{~min}$. Stresses in the layers were calculated using the XRD fundamental equation by Noyan [18]. The relation between the elastic strain $\left(\varepsilon_{\psi}^{h k l}\right)$ obtained for a certain $(h k l)$ diffraction at different $\psi$ directions of the sample and $\sin ^{2} \psi$ is presented in Equation (1):

$$
\varepsilon_{\psi}^{h k l}=\frac{d_{\psi}^{h k l}-d_{0}^{h k l}}{d_{0}^{h k l}}=\frac{1}{2} S_{2}(h k l) \sigma_{\|} \sin ^{2} \psi+2 S_{1}(h k l) \sigma_{\|}
$$

where $d_{\psi}^{h k l}$ is the lattice spacing obtained from the experiment for various reflections $h k l$, and $d_{o}^{h k l}$ is the strain-free lattice parameter of the material. $S 1(h k l)$ and $\frac{1}{2} S 2(h k l)$ are the diffraction elastic constants (DECs) valid for quasi-isotropic polycrystalline materials. They are independent of the measurement direction with respect to the sample system but reflect the elastic anisotropy of the crystallites of the layers. Equation (1) holds for a biaxial stress state of rotational symmetry, which is described by the in-plane stress component $\sigma_{\|}$[18]. Assuming a uniform stress state with respect to the layer thickness, $\mathrm{X}$-ray stress analysis using Equation (1) can be performed by applying the $\sin ^{2} \psi$ method [19] to the $d_{\psi}^{h k l}-\sin ^{2} \psi$ data sets that were obtained for different reflections $h k l$. Stress analysis on the investigated layers was performed for the diffraction lines summarized in Table 2 and the average of the resulting stress values was taken to monitor the stress evolution during thermal cycling. Further details about instrumentation and method have been extensively reported in a previous work by the authors [13]. 
Table 2. DECs for the investigated layers calculated by applying the Eshelby-Kröner model [20,21] using the respective single crystal elastic constants. For the stress evaluation in the $\mathrm{Ti}(\mathrm{C}, \mathrm{N})$ and $\mathrm{Zr}(\mathrm{C}, \mathrm{N})$ layers, an average value of the $\mathrm{DEC}$ for $\mathrm{TiC} / \mathrm{TiN}$ and $\mathrm{ZrC} / \mathrm{ZrN}$ was used, respectively.

\begin{tabular}{cccc}
\hline Component & $\boldsymbol{h k l}$ & $\boldsymbol{S}_{1}^{h k l}\left[\times 10^{-6} \mathbf{M P a}^{-1}\right]$ & $\frac{1}{2} \boldsymbol{S}_{2}^{h k l}\left[\times 10^{-6} \mathbf{M P a}^{-1}\right]$ \\
\hline$\alpha-\mathrm{Al}_{2} \mathrm{O}_{3}$ & $012 / 024$ & -0.685 & 3.36 \\
$\mathrm{Ti}(\mathrm{C}, \mathrm{N})$ & 200 & -0.425 & 2.665 \\
& 220 & -0.465 & 2.795 \\
$\mathrm{Zr}(\mathrm{C}, \mathrm{N})$ & 111 & -0.45 & 2.785 \\
& 220 & -0.44 & 2.755 \\
\hline
\end{tabular}

Residual theoretical and thermal stresses were calculated for each layer using Equation (2), assuming a plane-state of residual stress [22]:

$$
\sigma_{t h}=\frac{E_{L}}{\left(1-v_{L}\right)} *\left(C T E_{S}-C T E_{L}\right) *\left(T-T_{\text {max }}\right)
$$

where $\sigma_{\text {th }}$ is the residual thermal stress, $E_{L}$ is the Young's modulus of the layer, $v_{L}$ is the poisson coefficient of the layer, $T$ is the actual sample temperature, and $T_{\max }$ is the maximum temperature of the CVD deposition process, $C T E_{S}$ is the CTE for the substrate and $C T E_{L}$ is the CTE of the layer. Values used for calculations are presented in Table 1.

Micro-mechanical behavior of the carbonitride layers was investigated by micropillar uniaxial compression for single layered samples. Micropillars were milled in a FEI Helios NanoLab Dualbeam 600 SEM/FIB (Focused Ion Beam) using Ga ion beam. The compression test was carried out in a Hysitron Tribo-indenter T1900 equipped with a Performech controller and a diamond punch of $5 \mu \mathrm{m}$ diameter. For further details of sample preparation and experimental protocol, the readers are referred to the previous investigation by the authors [23].

Transmission Electron Microscopy (TEM) observations were done using a doublecorrected Thermo-Fisher-Scientific Titan G2 microscope operated at 300 KV. Dark field scanning TEM (STEM) images were taken at a camera distance of $73 \mathrm{~mm}$ from crystal grains tilted into low-index-zone axes to observe crystalline defects on the $\alpha-\mathrm{Al}_{2} \mathrm{O}_{3}$ top layer, as described in [13].

\section{Results and Discussion}

\subsection{Milling Tests}

SEM images of the wear evolution of the top-blasted $\operatorname{Ti}(\mathrm{C}, \mathrm{N}) / \alpha-\mathrm{Al}_{2} \mathrm{O}_{3}$ and $\mathrm{Zr}(\mathrm{C}, \mathrm{N}) / \alpha-$ $\mathrm{Al}_{2} \mathrm{O}_{3}$ coated inserts show a remarkable difference for both systems, as displayed in Figure 2. For both systems, a fine crack wear pattern starts to develop on the rake face of the inserts in the early stages of machining (two milled surfaces). These fine cracks grow mainly perpendicular to the cutting edge. Interestingly, the fine crack network on the rake face is more extended and visible in the $\operatorname{Zr}(\mathrm{C}, \mathrm{N})$ compared to the $\operatorname{Ti}(\mathrm{C}, \mathrm{N})$ system. At this stage slight flank wear is observed only in the $\operatorname{Ti}(\mathrm{C}, \mathrm{N})$ system. With further machining (4 surfaces) these fine cracks become comb cracks visible both in the rake and flank face in the $\operatorname{Ti}(\mathrm{C}, \mathrm{N})$ system which continue to grow and become larger and wider. 

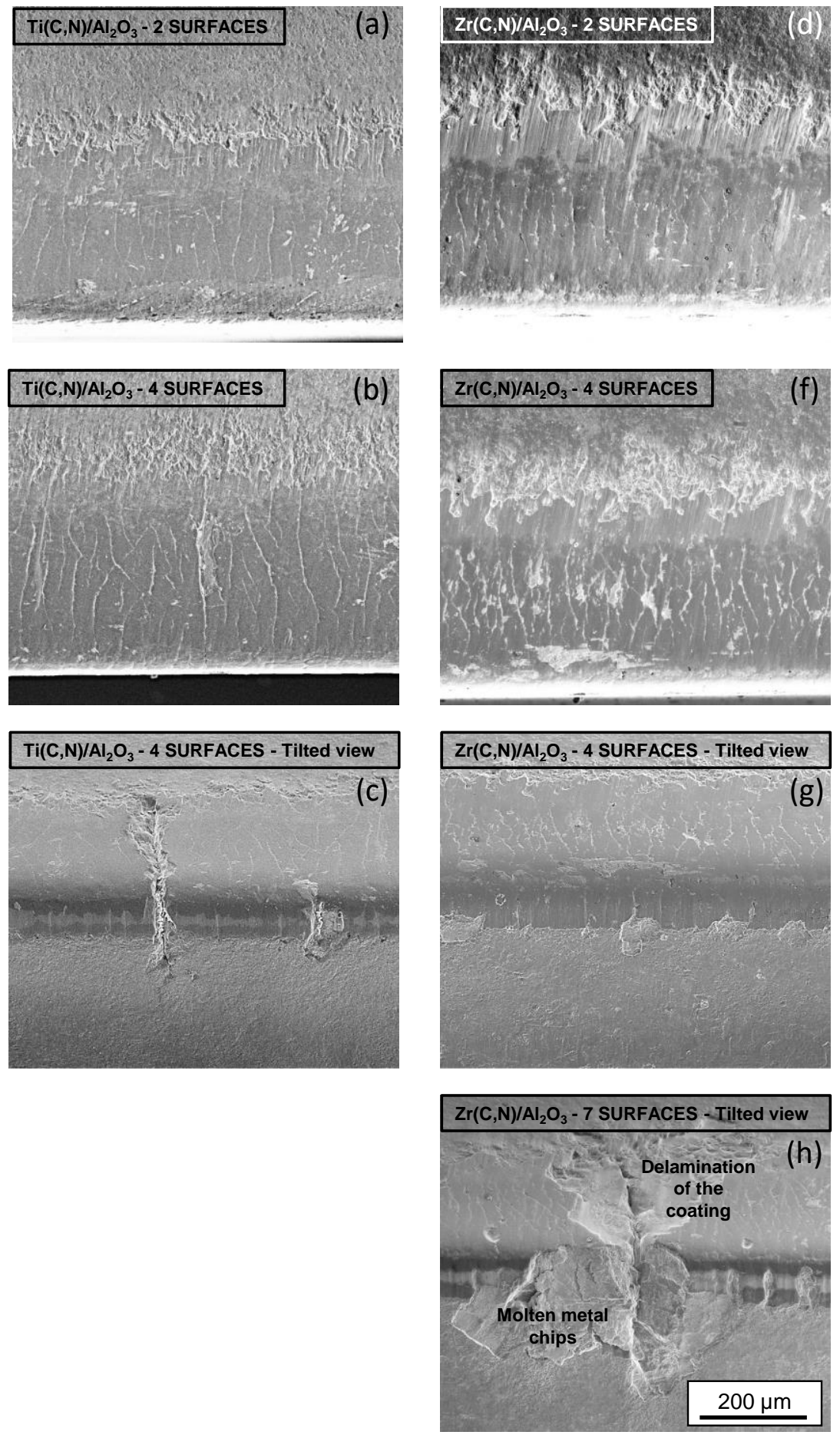

Figure 2. SEM images of the wear evolution for the $\mathrm{Ti}(\mathrm{C}, \mathrm{N}) / \alpha-\mathrm{Al}_{2} \mathrm{O}_{3}(\mathbf{a}-\mathbf{c})$ and $\mathrm{Zr}(\mathrm{C}, \mathrm{N}) / \alpha-\mathrm{Al}_{2} \mathrm{O}_{3}$ $(\mathbf{d}, \mathbf{f}, \mathbf{g}, \mathbf{h})$ systems for same number of milled surfaces. Evolution of comb cracking (starting from the fine cracks) can be seen with the number of milled surfaces. Clear delay in the formation of comb cracks and chipping for the $\mathrm{Zr}(\mathrm{C}, \mathrm{N})$ based system is observed. The outer surface seen is the $\alpha-\mathrm{Al}_{2} \mathrm{O}_{3}$.

At this stage it can be assumed that the extensive thermo-mechanical condition of the milling process together with the chemical and oxidation attack to the substrate favor the propagation of the cracks, some of them connecting, leading to chipping and extensive wear. In the $\mathrm{Zr}(\mathrm{C}, \mathrm{N})$ no clear comb cracks are formed after 4 surfaces, but wider opening of the fine crack wear pattern. Comb cracks appear after 7 milled surfaces for the $\operatorname{Zr}(C, N)$ based system in which the damage/delamination around the crack is wider. In terms 
of cutting performance (and if the tool life criteria is set to $0.25 \mathrm{~mm}$ length of cracks on the flank face) the tool life of the $\operatorname{Ti}(\mathrm{C}, \mathrm{N})$ based system is reached after 4 milled surfaces whereas the $\operatorname{Zr}(\mathrm{C}, \mathrm{N})$ based systems withstand 7 milled surfaces, indicating (according to the in-Lab tests) an increase of comb crack resistance of about $60 \%$.

\subsection{Wear Studies-Cracking}

To understand the observed difference in comb crack behavior, the mechanisms that lead to the formation of cracks were investigated. It has been experimentally reported and validated by modeling that the initiation of comb cracks in CVD coated inserts is connected to the CVD pre-crack network $[24,25]$. Furthermore, CVD cooling cracks in both rake and flank face network are considered to be the nucleus for the initiation of comb cracking as it is considered the most relevant defect that exists in the coating. The connection between the wear evolution and the pre-crack network of the coating originating from the CVD process is exemplified in Figure 3. At the tip of the cutting edge (where the contact force and temperature has reached its maxima [26]) an extended network of open cracks is observed. If we compare the crack pattern on the machined edge with the crack pattern in an area away and less affected by thermo-mechanical load, it is clear that the crack patterns opening/width has a kind of a gradient toward the machined part. The crack pattern in non-machined $\alpha-\mathrm{Al}_{2} \mathrm{O}_{3}$ is difficult to observe in the light optical microscope. A comparison with Figure 1 shows that the network of cracks is similar to the observed network after CVD coating, though the cracks are wider and more developed.

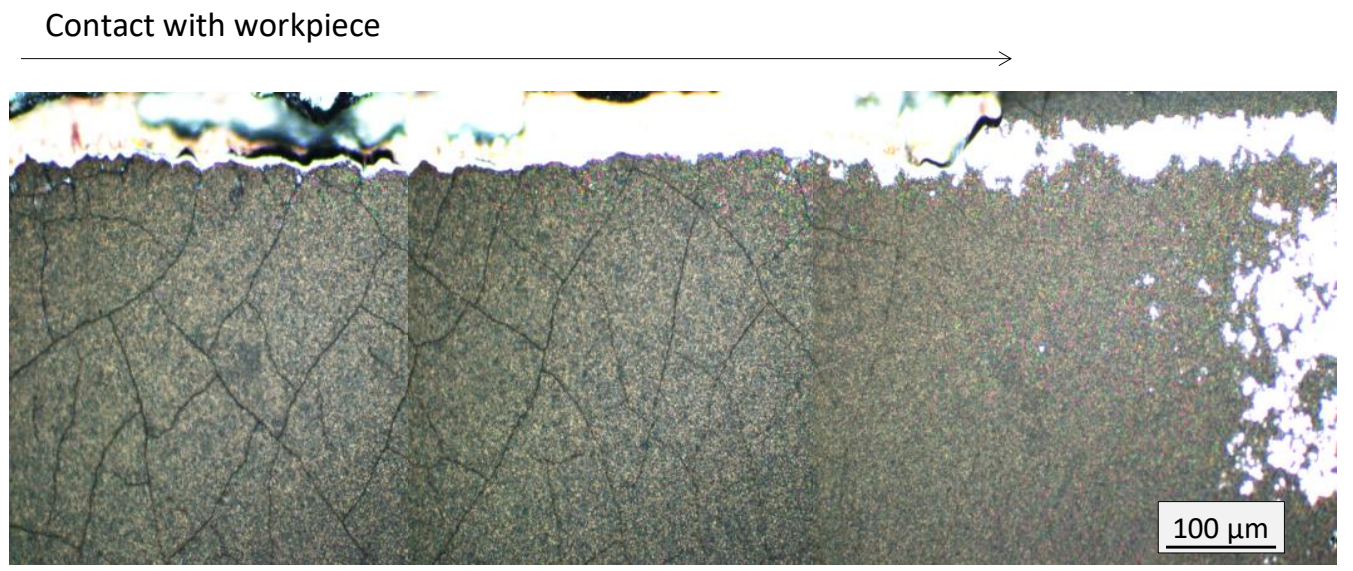

Figure 3. Worn edge after milling (5 surfaces) for the $\mathrm{Zr}(\mathrm{C}, \mathrm{N}) / \alpha-\mathrm{Al}_{2} \mathrm{O}_{3}$ system. The expanded crack network in the contact region with the workpiece is clearly visible.

Figure 4 shows the crack network in both the $\alpha-\mathrm{Al}_{2} \mathrm{O}_{3}$ and the carbonitride layers for both systems in the early stages of machining (the network of cracks has been extracted by imaging analysis for better visualization). For both systems the crack density is higher close to the cutting edge than further away from it. Small cracks with a spacing of 15 to $30 \mu \mathrm{m}$ with lengths of about $20 \mu \mathrm{m}$ have grown into the coating. Not all cracks present in the $\alpha-\mathrm{Al}_{2} \mathrm{O}_{3}$ have propagated down to the carbonitride layers; only a fraction of the cracks near the edge are present. Furthermore, the observed density of cracks in the $\operatorname{Zr}(\mathrm{C}, \mathrm{N})$ is less compared to the $\mathrm{Ti}(\mathrm{C}, \mathrm{N})$ layer, indicating that some of the $\alpha-\mathrm{Al}_{2} \mathrm{O}_{3}$ cracks did not propagate down through the $\mathrm{Zr}(\mathrm{C}, \mathrm{N})$ system. Recently, a similar behavior (CVD cooling cracks stopped at the intermediate $\operatorname{Zr}(\mathrm{C}, \mathrm{N})$ layer) was observed by FIB cross sectional imaging in similar systems [27]. It can be then concluded that the overall crack network structure in the two coating layers looks very similar, despite a less developed crack network is observed for the $\operatorname{Zr}(\mathrm{C}, \mathrm{N})$ compared to the $\operatorname{Ti}(\mathrm{C}, \mathrm{N})$ system. 

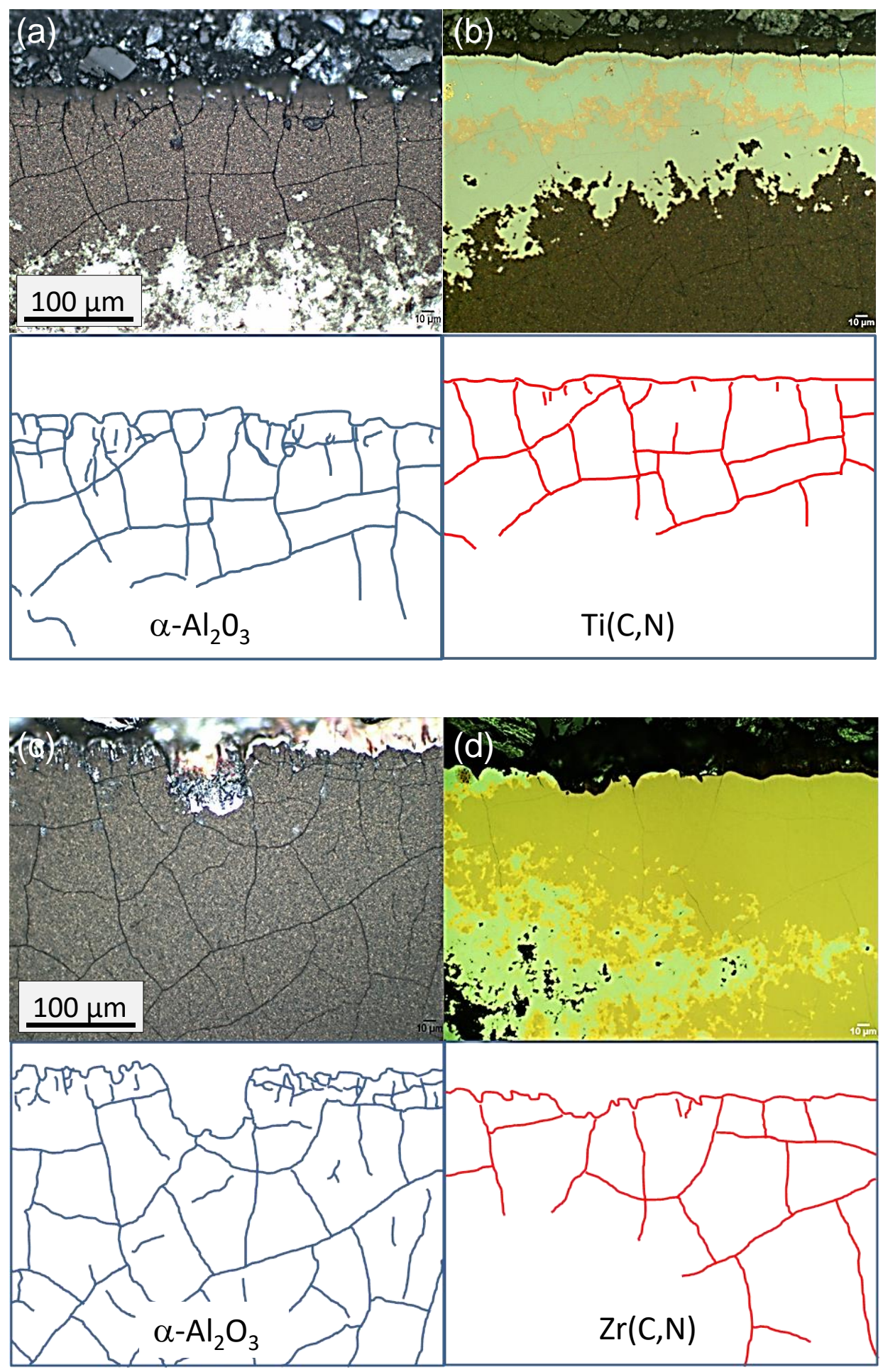

Figure 4. LOM images together with marked projection of comb crack network for the systems investigated after gentle polishing to reveal the comb cracks in the $\alpha-\mathrm{Al}_{2} \mathrm{O}_{3}(\mathbf{a}, \mathbf{c})$ and the underneath carbonitride layer $(\operatorname{Ti}(\mathrm{C}, \mathrm{N})(\mathbf{b})$ or $\mathrm{Zr}(\mathrm{C}, \mathrm{N})(\mathbf{d}))$. Images below represent better visualization of the cracks. Similar crack network in the $\alpha-\mathrm{Al}_{2} \mathrm{O}_{3}$ layer for both systems. The $\operatorname{Ti}(\mathrm{C}, \mathrm{N})$ layer presents a more dense network of cracks compared to the $\mathrm{Zr}(\mathrm{C}, \mathrm{N})$ layer.

\subsection{Residual and Thermal Stress Analysis}

The formation of the pre-crack network is associated with the large developed tensile stress during the cooling step of the CVD process originating from the CTE differences between the cemented carbide, the carbonitride and the alumina layers (see Table 1). The 
replacement of the $\operatorname{Ti}(\mathrm{C}, \mathrm{N})$ by the $\mathrm{Zr}(\mathrm{C}, \mathrm{N})$ intermediate layer (average CTE: $9.0 \times 10^{-6} / \mathrm{K}$ vs. $7.65 \times 10^{-6} / \mathrm{K}$ ) should impact the stress behavior both after coating deposition and during milling with cycling thermal loads. Furthermore, the cycling stress distribution at the cutting-edge during machining connected to the CVD pre-crack network impact the development of comb cracks [13]. Residual and thermal stress measurements are conducted in both systems in the as-deposited and top-blasted condition. Figure 5 displays the results of the in-situ stress evolution during two thermal cycles $\left(\mathrm{RT}-800{ }^{\circ} \mathrm{C}\right)$ for the $\mathrm{Zr}(\mathrm{C}, \mathrm{N}) / \alpha-\mathrm{Al}_{2} \mathrm{O}_{3}$ and the $\mathrm{Ti}(\mathrm{C}, \mathrm{N}) / \alpha-\mathrm{Al}_{2} \mathrm{O}_{3}$ systems in both as-coated and top-blasted conditions. For the as-coated condition (Figure $5 \mathrm{a}$ ) the $\alpha-\mathrm{Al}_{2} \mathrm{O}_{3}$ layer presents a similar behavior for both the $\operatorname{Ti}(\mathrm{C}, \mathrm{N})$ and the $\operatorname{Zr}(\mathrm{C}, \mathrm{N})$ systems. However considerable higher compressive stresses of the $\mathrm{Zr}(\mathrm{C}, \mathrm{N})$ layer compared to the $\mathrm{Ti}(\mathrm{C}, \mathrm{N})$ layer are observed over the two thermal cycles, which is an indication of the effect of the low CTE of the $\operatorname{Zr}(\mathrm{C}, \mathrm{N})$ layer on the development of the residual and thermal stresses.
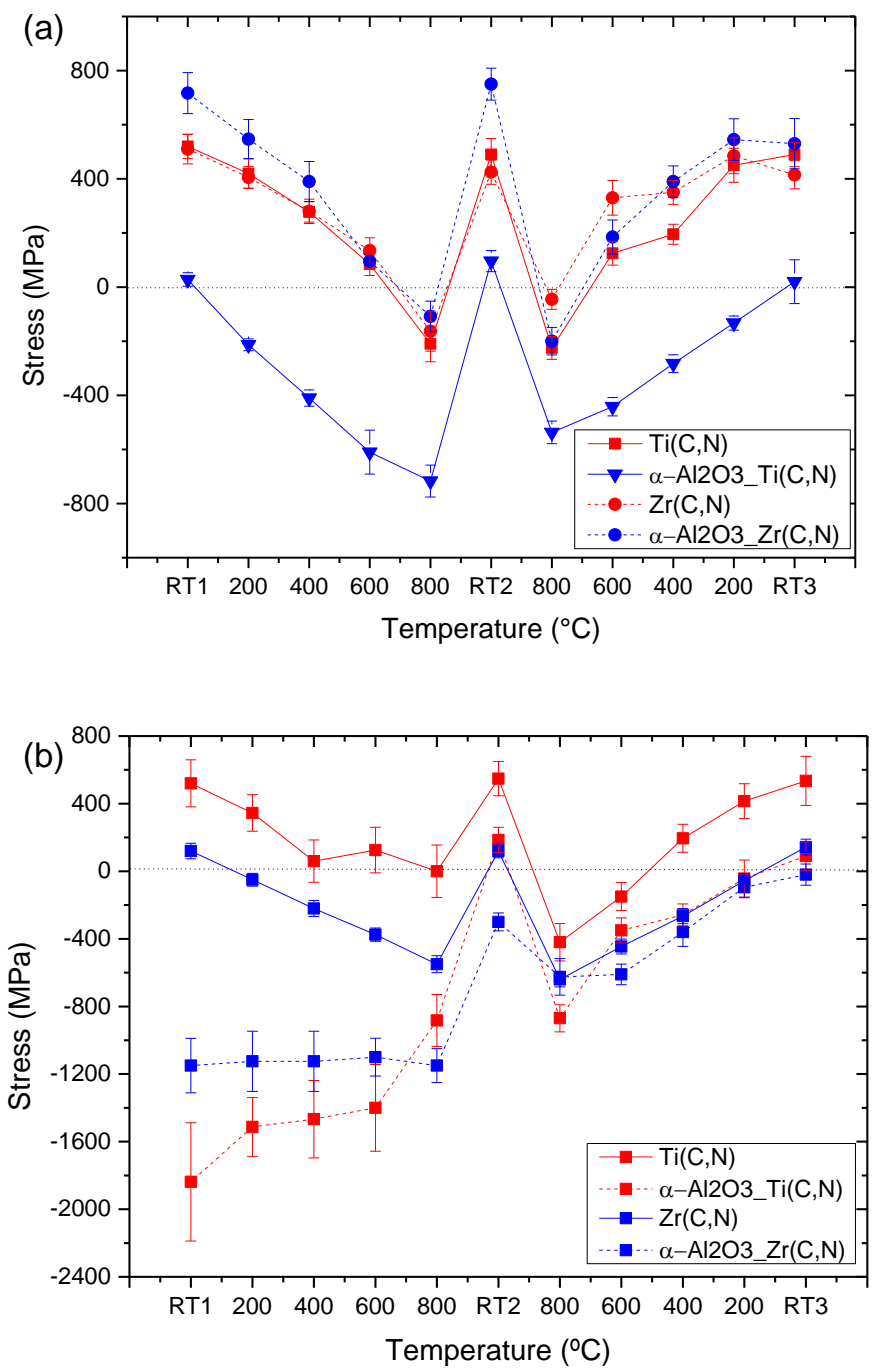

Figure 5. In situ determined stresses for the $\mathrm{Zr}(\mathrm{C}, \mathrm{N}) / \alpha-\mathrm{Al}_{2} \mathrm{O}_{3}$ and the $\mathrm{Ti}(\mathrm{C}, \mathrm{N}) / \alpha-\mathrm{Al}_{2} \mathrm{O}_{3}$ systems for the as-coated (a) and top-blasted (b) conditions.

In the top-blasted condition (Figure $5 \mathrm{~b}$ ) high compressive stresses are introduced in the $\alpha-\mathrm{Al}_{2} \mathrm{O}_{3}$ layer in both systems, a technique that has been reported in literature $[6,9,28]$ and it is widely used in industry to increase the tool life of cutting inserts [29]. The $\alpha-\mathrm{Al}_{2} \mathrm{O}_{3}$ layer remain in compressive stress in the first heat cycle, releasing the induced top-blasted stresses after the second thermal cycle. It can be seen from STEM images (Figure 6) that a high density of defects (dislocations and stacking faults [13]) are introduced after blasting 
in the $\alpha-\mathrm{Al}_{2} \mathrm{O}_{3}$ for both $\mathrm{Ti}(\mathrm{C}, \mathrm{N})$ and $\mathrm{Zr}(\mathrm{C}, \mathrm{N})$ grades, and that after annealing the density of these defects decreases. The physical understanding of this phenomenon connecting the residual stress behavior and the microstructural changes during thermal cycling has been recently reported [13], concluding that the high stresses introduced by blasting are connected to a high density of defects in the $\alpha-\mathrm{Al}_{2} \mathrm{O}_{3}$ and the subsequent relaxation by thermal treatment is driven by annihilation of defects in a diffusion driven phenomena. The temperature dependent stress behavior of the $\operatorname{Ti}(\mathrm{C}, \mathrm{N})$ and $\operatorname{Zr}(\mathrm{C}, \mathrm{N})$ layer is almost the same for both the as-coated and top-blasted states. It can be assumed -as demonstrated for the $\operatorname{Ti}(\mathrm{C}, \mathrm{N})$ layer [13] that the reversible stress behavior of the $\operatorname{Zr}(\mathrm{C}, \mathrm{N})$ is not associated to changes in defects (dislocations, stacking faults) and presents an elastic deformation behavior in the temperature range investigated.
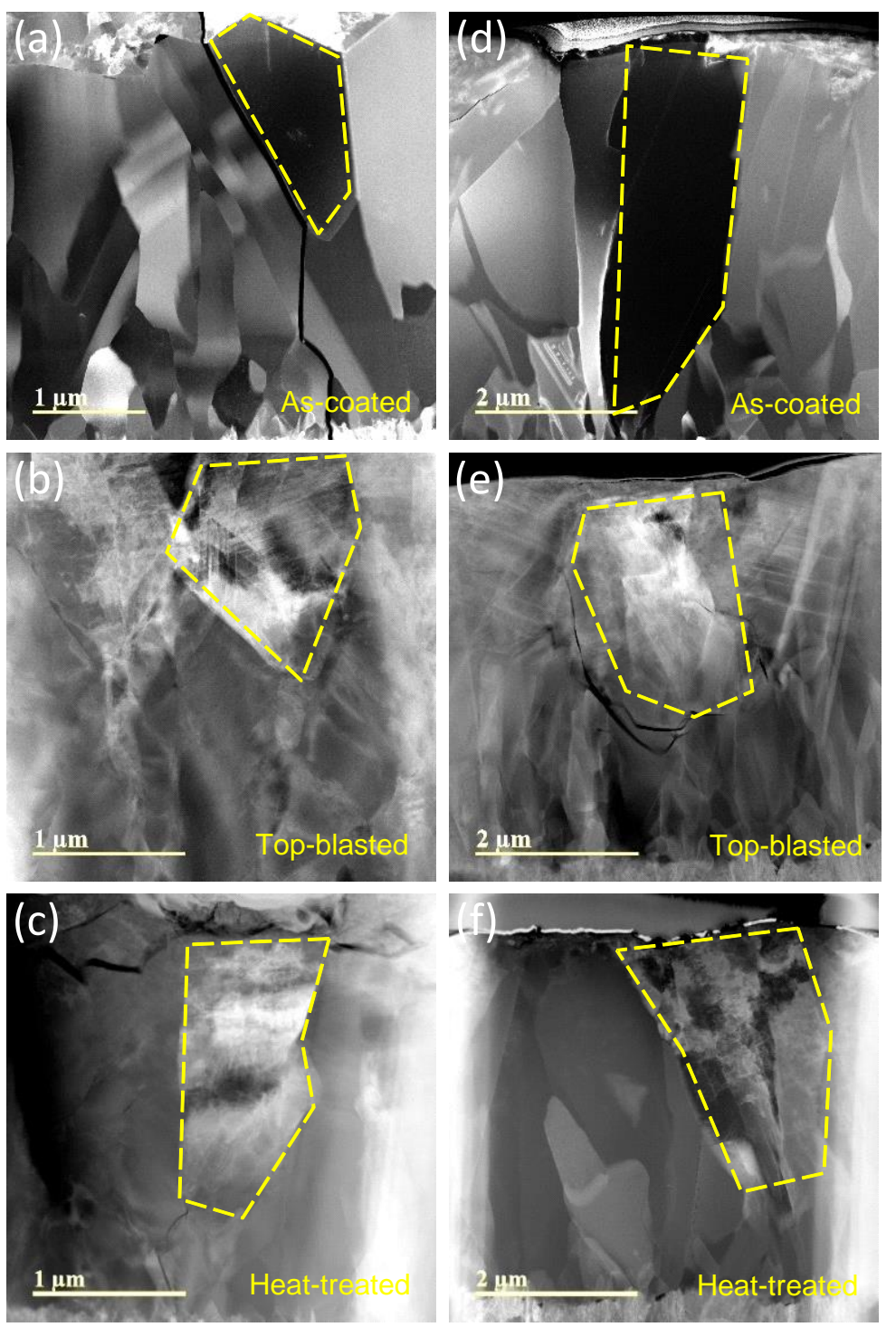

Figure 6. Dark-field STEM images of $\alpha-\mathrm{Al}_{2} \mathrm{O}_{3}$ grains in the $\alpha-\mathrm{Al}_{2} \mathrm{O}_{3} / \mathrm{Ti}(\mathrm{C}, \mathrm{N})(\mathbf{a}-\mathbf{c})$ and $\alpha$ $\mathrm{Al}_{2} \mathrm{O}_{3} / \mathrm{Zr}(\mathrm{C}, \mathrm{N})(\mathbf{d}-\mathbf{f})$ samples in different conditions, acquired with one of the grains (marked by the yellow polygons) tilted to a zone axis. The growth direction is towards the top of the images. It can be seen that defects introduced by blasting decreases after annealing.

Another important observation is the difference between the theoretical stresses and the ones estimated by synchrotron X-ray diffraction. The lower estimated stresses in the investigated samples show the effect of the relaxation due to thermal-cracking in the CVD 
process. This difference between theoretical and estimated stresses remains almost equal for the temperature cycling conditions at all temperatures (see extracted data in Table 3).

Table 3. Theoretical vs. averaged estimated residual and thermal stresses for the systems investigated at $\mathrm{RT}$ and $800^{\circ} \mathrm{C}$.

\begin{tabular}{ccccc}
\hline Coating Layer & Temperature $\left[{ }^{\circ} \mathrm{C}\right]$ & Theoretical & As-Coated & Top-Blasted \\
\hline & & $\sigma_{\text {II THEOR [MPa] }}$ & $\sigma_{\text {II XRD [MPa] }}$ & $\sigma_{\text {II XRD [MPa] }}$ \\
\hline$\alpha-\mathrm{Al}_{2} \mathrm{O}_{3}$ & $\mathrm{RT}$ & 1490 & 500 & -1800 \\
& 800 & 305 & -150 & -800 \\
$\mathrm{Ti}(\mathrm{C}, \mathrm{N})$ & $\mathrm{RT}$ & 1800 & 500 & 500 \\
& 800 & 382 & -200 & -100 \\
$\alpha-\mathrm{Al}_{2} \mathrm{O}_{3}$ & $\mathrm{RT}$ & 1490 & 500 & -1200 \\
& 800 & 305 & -150 & -1100 \\
$\mathrm{Zr}(\mathrm{C}, \mathrm{N})$ & $\mathrm{RT}$ & 940 & 50 & 80 \\
& 800 & 204 & -700 & -600 \\
\hline
\end{tabular}

As described in the introduction of this work, the motivation of replacing the intermediate carbonitride layer of the multilayer CVD coating system aimed at investigating the effect on the stress behavior of the systems at cycling temperature loads. The stress investigations validated the initial hypothesis that a carbonitride layer with a lower CTE will set a lower tensile stress load on the coating system. Furthermore, when comparing the stress amplitude for both systems determined by in-situ synchrotron measurements in the temperature range $25-800{ }^{\circ} \mathrm{C}$ (Figure 7) and assuming that the variation of thermal loads in a milling machining operation is between 200 and $600^{\circ} \mathrm{C}[30]$ a $\mathrm{Zr}(\mathrm{C}, \mathrm{N})$ based coating system should be more favorable to retard crack formation and propagation compared to a $\mathrm{Ti}(\mathrm{C}, \mathrm{N})$ based coating system.

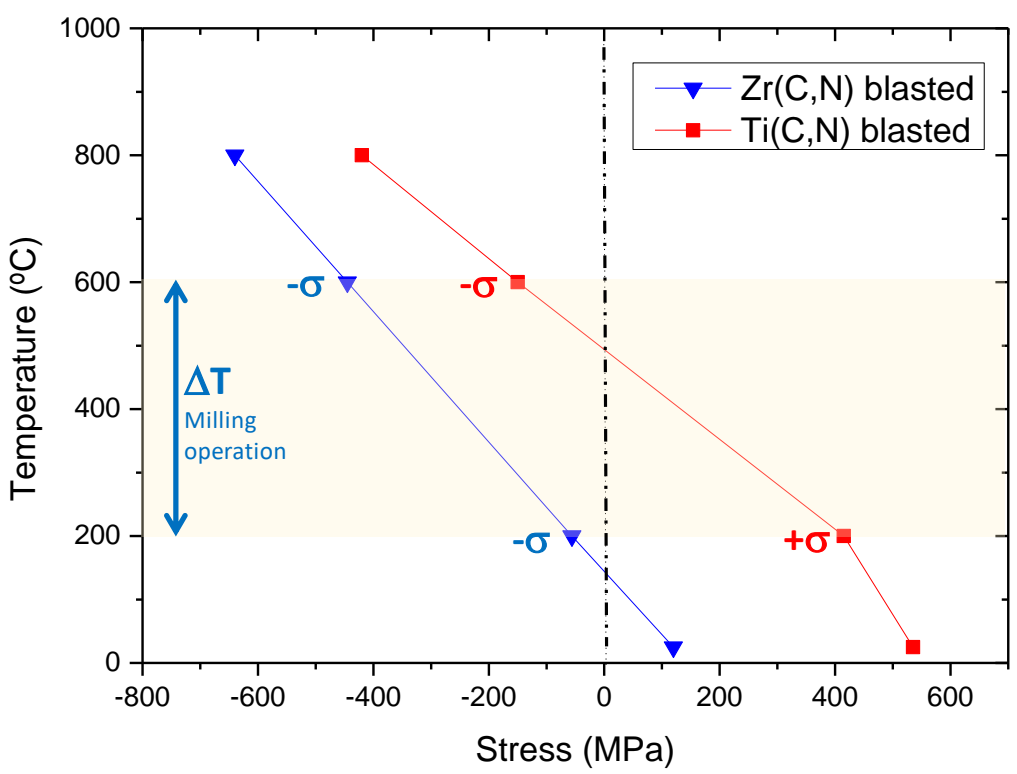

Figure 7. Reversible cycling stress amplitudes for the $\mathrm{Zr}(\mathrm{C}, \mathrm{N})$ and $\operatorname{Ti}(\mathrm{C}, \mathrm{N})$ layers (in $\operatorname{Ti}(\mathrm{C}, \mathrm{N}) / \alpha-\mathrm{Al}_{2} \mathrm{O}_{3}$ and $\mathrm{Zr}(\mathrm{C}, \mathrm{N}) / \alpha-\mathrm{Al}_{2} \mathrm{O}_{3}$ systems) determined by in-situ synchrotron measurements (temperature range: $\left.25-800^{\circ} \mathrm{C}\right)$. The temperature fluctuation in wet milling of cast iron is highlighted.

The reason is that the stress within the $\mathrm{Zr}(\mathrm{C}, \mathrm{N})$ coating system remains mostly compressive during the alternating cycling thermal loads. For the case of the $\operatorname{Ti}(\mathrm{C}, \mathrm{N})$ based coating system, the stress state is reversible, varying between tensile (at lower temperatures) and compressive (at higher temperatures); a condition of oscillating cycling stresses (tensile-compressive-tensile) favorable for crack opening and propagation. 


\subsection{Crack Propagation Path and Deformation Behavior}

Comb cracks at end tool life have been studied by sequential polishing, starting from the outer $\alpha-\mathrm{Al}_{2} \mathrm{O}_{3}$ layer (Figure 8). The studies show a crack path connected to the CVD cooling crack network in both systems, but a different morphology in both systems. The $\mathrm{Ti}(\mathrm{C}, \mathrm{N})$ cracks present a typical brittle crack propagation (Figure 8$)$. However, the comb cracks in the $\mathrm{Zr}(\mathrm{C}, \mathrm{N})$ system form later in the machining process. These cracks are short and thick. Signs of breakage around the crack are visible both in the $\alpha-\mathrm{Al}_{2} \mathrm{O}_{3}$ and the $\mathrm{Zr}(\mathrm{C}, \mathrm{N})$ layer. As mentioned in the wear studies of the milling inserts, no visible cracks were identified in the first steps of the milling process for $\mathrm{Zr}(\mathrm{C}, \mathrm{N}) / \alpha-\mathrm{Al}_{2} \mathrm{O}_{3}$ (see Figure 2).
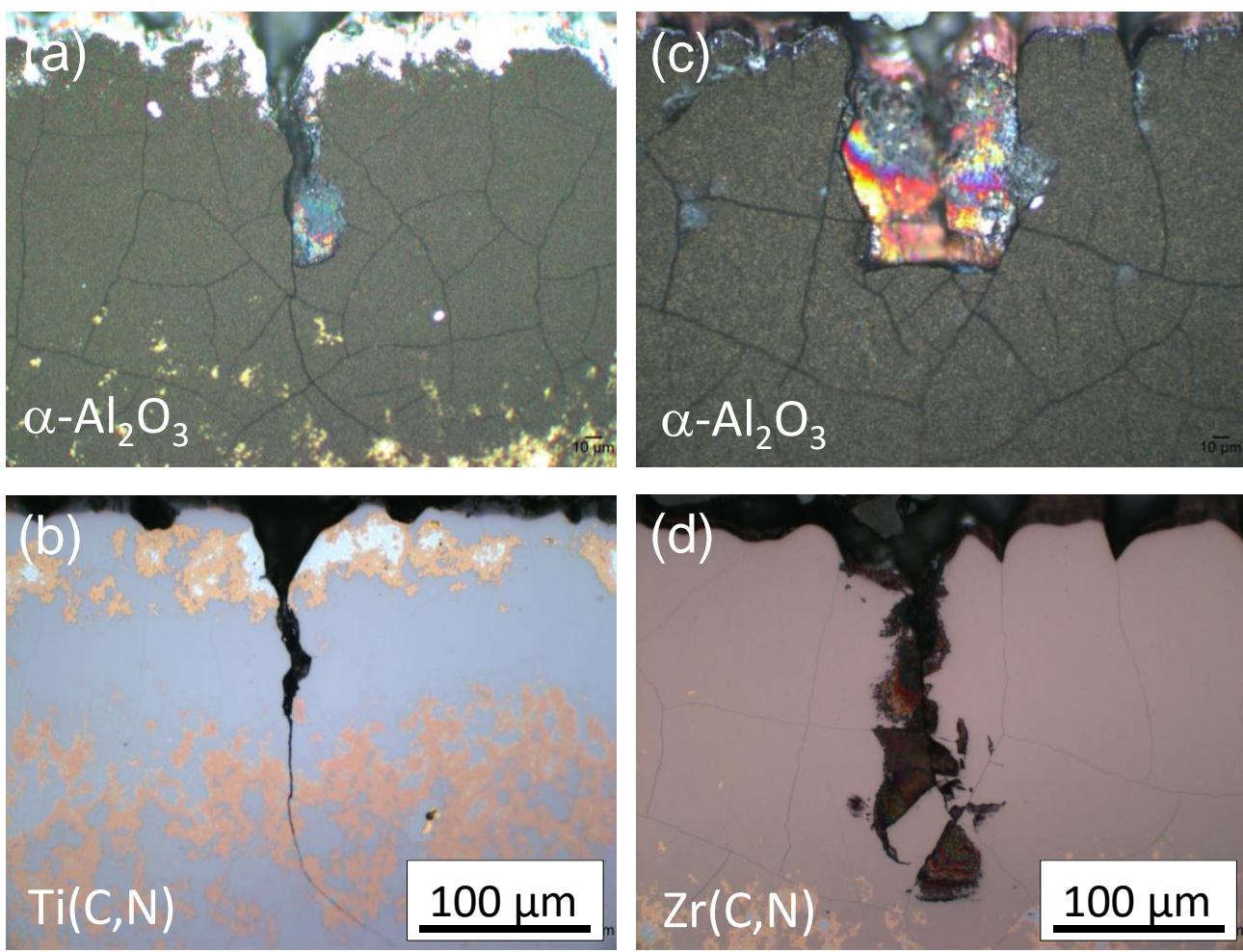

Figure 8. Comb crack morphology revealed after sequential polishing of the cutting edge for $\mathrm{Ti}(\mathrm{C}, \mathrm{N}) / \alpha-\mathrm{Al}_{2} \mathrm{O}_{3}(\mathbf{a}, \mathbf{b})$ and $\mathrm{Zr}(\mathrm{C}, \mathrm{N}) / \alpha-\mathrm{Al}_{2} \mathrm{O}_{3}(\mathbf{c}, \mathbf{d})$ systems. Comb cracks propagate on existing CVD cooling crack network. The morphology of the cracks differs for the $\operatorname{Ti}(\mathrm{C}, \mathrm{N})(\mathrm{b})$ and the $\mathrm{Zr}(\mathrm{C}, \mathrm{N})$ (d)-based systems.

This remarkable difference in wear behavior can be attributed to the physical and mechanical properties of $\mathrm{Zr}(\mathrm{C}, \mathrm{N})$, which helps delaying initiation and propagation of comb cracks. In previous investigations by the authors [23], $\mathrm{Zr}(\mathrm{C}, \mathrm{N})$ has demonstrated strong evidences of plastic deformation in comparison to $\mathrm{Ti}(\mathrm{C}, \mathrm{N})$ as seen from micropillar compression tests. This is attributed to the $\mathrm{Zr}(\mathrm{C}, \mathrm{N})$ possessing enhanced toughness during deformation while maintaining similar stiffness and hardness as $\operatorname{Ti}(\mathrm{C}, \mathrm{N})$. It was even evidenced that $\operatorname{Zr}(\mathrm{C}, \mathrm{N})$ can deform plastically with the substrate for a hybrid pillar assembly under compression [31]. Additionally, it has been proven that $\mathrm{ZrC}$ single crystals (which are similar to the $\mathrm{Zr}(\mathrm{C}, \mathrm{N})$ ) show plastic deformation under uniaxial loading due to the activation of unexpected slip planes at room temperature [32]. This behavior could also be expected for other transition metal carbides from groups 4 and 5 such as $\mathrm{TiC}$, but the overall ductility in group 4 is expected to increase from $\mathrm{TiC}$ to $\mathrm{ZrC}$. Besides, $\mathrm{ZrC}$ is expected to have increased ductility with increasing temperature in comparison to the $\mathrm{TiC}$ [33]. Moreover, a recent theoretical study suggests that the stiffness and fracture toughness increase with nitrogen fraction in $\mathrm{Zr}(\mathrm{C}, \mathrm{N})$ compounds [34]. 
Micropillars were compressed in the uniaxial load to determine crack propagation path in both coatings. In Figure 9 it can be observed that $\mathrm{Ti}(\mathrm{C}, \mathrm{N})$ deforms as an array of assembled columnar grains which dissociate and fail at the grain boundaries. Meanwhile, $\mathrm{Zr}(\mathrm{C}, \mathrm{N})$ deforms as one structure and with mainly the transgranular crack propagation mode, which was reported in the previous finding of the authors [23]. The facets of failing columnar grains are smooth for $\mathrm{Ti}(\mathrm{C}, \mathrm{N})$ while serrations are seen for $\mathrm{Zr}(\mathrm{C}, \mathrm{N})$ (Figure 9). These serrations are an indication of less brittle or ductile fracture behavior. Furthermore, these results validate previous studies reporting that -in contrast to $\mathrm{Zr}(\mathrm{C}, \mathrm{N})$ - intergranular crack propagation path is characteristic for $\operatorname{Ti}(\mathrm{C}, \mathrm{N})$ either for tests carried out in the microstructural scale or at the macro-scale, indicating that the lower cohesive strength at the grain boundaries for $\operatorname{Ti}(\mathrm{C}, \mathrm{N})$ is an intrinsic property of the coating-independent from the length scale of the test $[23,27]$. The reason behind this observation has been associated with the exclusive segregation of chlorine at the grain boundaries for the titanium coating which decreases the cohesive strength at the boundaries of the coating's interfaces [35].
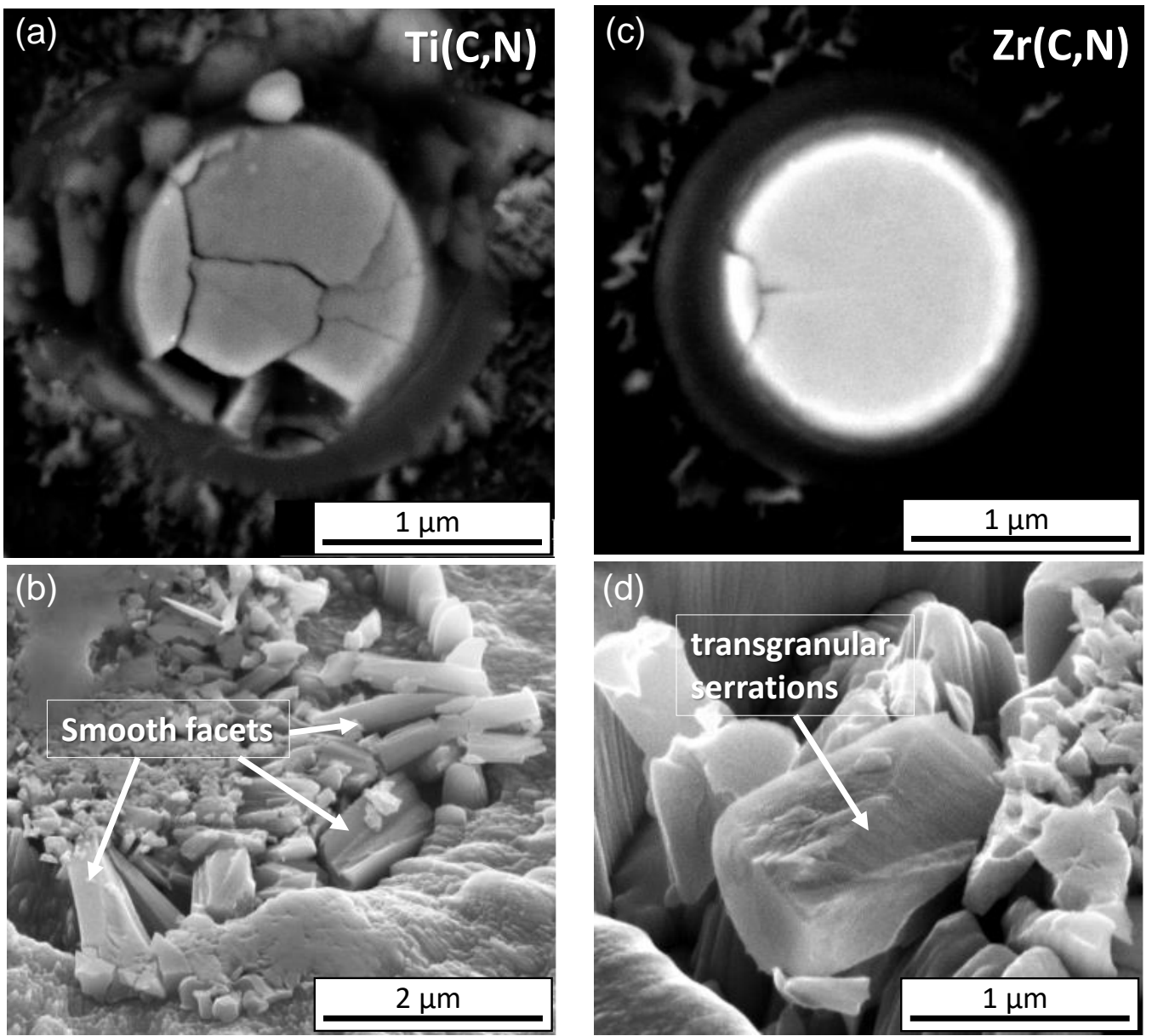

Figure 9. Comparison between failure mechanisms of $\operatorname{Ti}(C, N)(\mathbf{a}, \mathbf{b})$ and $\operatorname{Zr}(C, N)(\mathbf{c}, \mathbf{d})$ micropillars. Initiation of failure at the grain boundaries are noticed in the case of $\mathrm{Ti}(\mathrm{C}, \mathrm{N})$. After catastrophic failure of micropillars smooth facets for $\mathrm{Ti}(\mathrm{C}, \mathrm{N})$ grains are observed $(\mathbf{b})$, whereas serrations in the $\mathrm{Zr}(\mathrm{C}, \mathrm{N})$ grains are visible $(\mathbf{d})$.

To summarize, the synergy of these effects, which are better cohesive strength at the grain boundaries and plastic deformation will assign to the $\operatorname{Zr}(\mathrm{C}, \mathrm{N})$ better fracture toughness for the initiation and propagation of cracks, which is advantageous during cooling down (after the deposition) and during intermittent cutting. 


\subsection{Comb Crack Model}

From a wear perspective, the increased wear resistance is attributed to the delayed/ postponed appearance of comb cracks for cutting inserts coated with $\operatorname{Zr}(\mathrm{C}, \mathrm{N})$ in contrast to $\mathrm{Ti}(\mathrm{C}, \mathrm{N})$. During cutting, comb cracks will be initiated from the existing defects, which are mainly CVD cooling cracks. As a summary, the main steps of comb crack wear evolution in the investigated system are described schematically in Figure 10. The sequence of wear during milling for both systems is simplified and main wear steps are highlighted for both the $\operatorname{Ti}(\mathrm{C}, \mathrm{N})$ and the $\mathrm{Zr}(\mathrm{C}, \mathrm{N})$ systems. It is very important to highlight that comb cracking also occurs for non-coted cemented carbides. It was reported that coating increases the resistance to comb cracking in comparison to non-coated case. In intermittent cutting, cracking is the most dominant mechanism controlling wear and failure of cemented carbide tool [3]. CVD cooling cracks in both rake and flank face network are the nucleus for the initiation of comb cracking as it is considered the most relevant defect that exists in the coating. In earlier cutting stages, a specific wear structure within the coating in the rake face appears, which are perpendicular fine cracks to the edge referred to as "wrinkles". These wrinkles emerge from the perpendicular cracks to the edge of the CVD network, which grow and extend (Figure 10a). In the flank face, periodic "teeth" appear at the cutting edge (Figure 10b). As the cutting milling continues, these structures are more developed: perpendicular wrinkles become wide ridges that continue to grow, reaching the substrate and deepen perpendicularly to the edge until very fine comb cracks appear/emerge in the flank face (Figure 10c,d). The position of these fine comb cracks depends on the stress distribution at the cutting-edge during cutting. It was reported experimentally and validated later by modeling that the build-up of important tensile stress in specific regions in the rake face coincide with the position of comb cracking [3,25]. As a consequence, fine comb cracks grow with damage and chipping around the cracks. Lateral cracks coming from comb cracks in the flank face connect with the comb cracks, which results in chipping of fragments at the edge and finally failing of the cutting edge (Figure 10e).

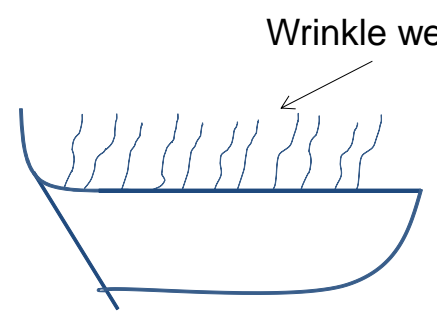

(a)

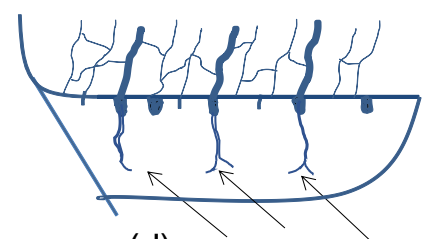

(d)

Comb cracks

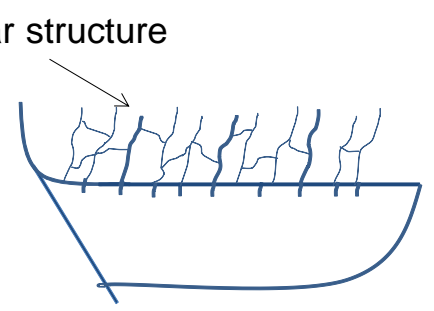

(b)

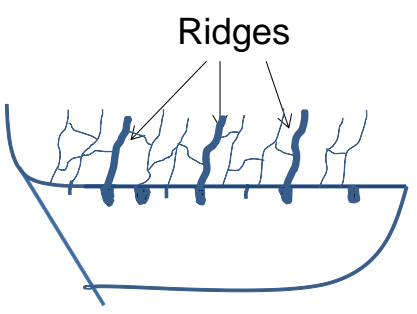

(c)

Figure 10. Main steps of wear evolution during milling of cast iron for both $\operatorname{Ti}(\mathrm{C}, \mathrm{N}) / \alpha-\mathrm{Al}_{2} \mathrm{O}_{3}$ system and $\mathrm{Zr}(\mathrm{C}, \mathrm{N}) / \alpha-$ $\mathrm{Al}_{2} \mathrm{O}_{3}$ system.

\section{Conclusions}

The results of this work show that the wear development and comb crack resistance of milling inserts cannot be attributed to a main factor, but to the linking between the residual stresses behavior, deformation behavior and physical or chemical characteristic of the coating/carbide systems. In the present investigation, the comb crack resistance differs considerably if the $\operatorname{Ti}(\mathrm{C}, \mathrm{N})$ intermediate layer is replaced by a $\operatorname{Zr}(\mathrm{C}, \mathrm{N})$ layer in the 
carbonitride $/ \alpha-\mathrm{Al}_{2} \mathrm{O}_{3}$ CVD system. The main conclusions that clearly shows the effect of tailoring surface properties can be summarized as follows:

- The wear evolution shows the early formation of comb cracks for the Ti(C,N) system, the formation of a fine crack pattern in the rake face and the late appearance of comb cracks for the $\operatorname{Zr}(\mathrm{C}, \mathrm{N})$ system. This reflects in a longer tool life for the $\operatorname{Zr}(\mathrm{C}, \mathrm{N})$ system.

- A connection between the CVD cooling crack network, the wear evolution, and the final formation of comb cracks was observed.

- The Ti(C,N) layer shows a reversible tensile-compressive-tensile cycling stress behavior in the temperature range of the intermittent machining milling process that favors comb crack opening and growth.

- The impact of the lower coefficient of thermal expansion of the $\operatorname{Zr}(\mathrm{C}, \mathrm{N})$ layer reflects in lower tensile stresses compared to the $\mathrm{Ti}(\mathrm{C}, \mathrm{N})$ system. Moreover, the stresses in the $\mathrm{Zr}(\mathrm{C}, \mathrm{N})$ system remains compressive in the temperature range $200-600^{\circ} \mathrm{C}$.

- Top-blasting induce high compressive stresses in the $\alpha-\mathrm{Al}_{2} \mathrm{O}_{3}$ layer in both systems, which stems from the generation of defects and dislocations. After annealing, compressive stresses due to blasting are released in both systems.

- The morphology of the comb cracks differs for the $\mathrm{Zr}(\mathrm{C}, \mathrm{N})$ and $\mathrm{Ti}(\mathrm{C}, \mathrm{N})$ systems, showing thin long cracks in the Ti(C,N) system and wide short cracks in the $\operatorname{Zr}(\mathrm{C}, \mathrm{N})$ system.

- In the micro-mechanical tests, the fracture of the polycrystalline Ti $(\mathrm{C}, \mathrm{N})$ coating proceeds by brittle behavior between the coating crystallites, whereas the polycrystalline $\mathrm{Zr}(\mathrm{C}, \mathrm{N})$ coating fracture is accompanied by signs of plastic deformation as observed in the transgranular serrations of the broken crystal.

- Summarizing the combination of the reduced tensile stress level, the observed reversible compressive stress in the range $200-600{ }^{\circ} \mathrm{C}$ and the more ductile behavior of the $\operatorname{Zr}(\mathrm{C}, \mathrm{N})$ system makes it more resistant to the formation of thermo-mechanical driven cracks in CVD coated milling inserts.

Author Contributions: Conceptualization, I.E.A. and J.G.; methodology, M.M. (Maiara Moreno), I.E.A., D.A., M.M. (Matthias Meixner) and J.G.; formal analysis and investigation, M.M. (Maiara Moreno), I.E.A., W.W., D.A., M.M. (Matthias Meixner) and J.G.; resources, F.S., F.M. and J.G.; writingoriginal draft preparation, M.M. (Maiara Moreno), I.E.A. and J.G.; writing-review and editing, M.M. (Maiara Moreno), I.E.A. and J.G.; visualization, M.M. (Maiara Moreno), I.E.A. and J.G.; project administration, H.P., F.S., F.M. and J.G.; funding acquisition, H.P.,F.S., F.M. and J.G. All authors have read and agreed to the published version of the manuscript.

Funding: This research was funded by the European Comission through the project: Erasmus Mundus Doctoral Programme DocMASE, RISE Project CREATe-Network (grant number 644013). The APC was funded by Deutsche Forschungsgemeinschaft (DFG, German Research Foundation) and Saarland University within the funding programme Open Access Publishing.

Data Availability Statement: The data presented in this study are available on request from the corresponding author. The data are not publicly available.

Acknowledgments: Daniel Karlsson (former master student at Sandvik Coromant) is acknowledged for the research developed in wear studies of comb cracks. Jeanette Persson (CVD coating) from AB Sandvik Coromant R\&D is acknowledged for experimental support in this work.

Conflicts of Interest: The authors declare no conflict of interest. The funders had no role in the design of the study, in the collection, analyses, or interpretation of data, in the writing of the manuscript, and in the decision to publish the results.

\section{References}

1. García, J.; Ciprés, V.C.; Blomqvist, A.; Kaplan, B. Cemented carbide microstructures: A review. Int. J. Refract. Met. Hard Mater. 2019, 80, 40-68. [CrossRef]

2. Teppernegg, T.; Klünsner, T.; Angerer, P.; Tritremmel, C.; Czettl, C.; Keckes, J.; Ebner, R.; Pippan, R. Evolution of residual stress and damage in coated hard metal milling inserts over the complete tool life. Int. J. Refract. Met. Hard Mater. 2014, 47, 80-85. [CrossRef] 
3. Bhatia, S.; Pandey, P.; Shan, H. The thermal condition of the tool cutting edge in intermittent cutting. Wear 1980, 61, 21-30. [CrossRef]

4. García, J.; Pitonak, R.; Weissenbacher, R.; Köpf, A.; Soldera, F.; Suarez, S.; Miguel, F.; Pinto, H.; Kostka, A.; Mücklich, F. Design and characterization of novel wear resistant multilayer CVD coatings with improved adhesion between $\mathrm{Al}_{2} \mathrm{O}_{3}$ and $\mathrm{Ti}_{(\mathrm{C}}(\mathrm{N})$. Adv . Eng. Mater. 2010, 12, 929-934. [CrossRef]

5. Stylianou, R.; Velic, D.; Daves, W.; Ecker, W.; Tkadletz, M.; Schalk, N.; Czettl, C.; Mitterer, C. Thermal crack formation in $\mathrm{Ti}(\mathrm{C}, \mathrm{N}) / \mathrm{Al}_{2} \mathrm{O}_{3}$ bilayer coatings grown by thermal CVD WC-Co substrates with varied Co content. Surf. Coat. Technol. 2020, 392, 125687. [CrossRef]

6. Schalk, N.; Mitterer, C.; Czettl, C.; Sartory, B.; Penoy, M.; Michotte, C. Dry blasting of alpha and kappa- $\mathrm{Al}_{2} \mathrm{O}_{3} \mathrm{CVD}$ hard coatings: Friction behavior and thermal stress relaxation. Tribol. Lett. 2013, 52, 147-154. [CrossRef]

7. Gassner, M.; Schalk, N.; Tkadletz, M.; Czettl, C.; Mitterer, C. Thermal crack network on CVD TiCN $/ \alpha-\mathrm{Al}_{2} \mathrm{O}_{3}$ coated cemented carbide cutting tools. Int. J. Ref. Met. Hard Mater. 2019, 81, 1-6. [CrossRef]

8. Faksa, L.; Daves, W.; Ecker, W.; Klünsner, T.; Tkadletz, M.; Czettl, C. Effect of shot peening on residual stresses and crack closure in CVD coated hard metal cutting inserts. Int. J. Refract. Met. Hard Mater. 2019, 82, 174-182. [CrossRef]

9. Barbatti, C.; García, J.; Pinto, H.; Kostka, A.; di Prinzio, A.; Staia, M.; Pitonak, R.; Pyzalla, A. Influence of micro-blasting on the microstructure and residual stresses of $\mathrm{CVD}$ k- $\mathrm{Al}_{2} \mathrm{O}_{3}$ coatings. Surf. Coat. Technol. 2009, 203, 3708-3717. [CrossRef]

10. García, J.; Pinto, H.; Ramos-Moore, E.; Espinoza, C.; Östby, J.; Coelho, R. In-situ high temperature stress analysis of Ti(C,N) coatings on functionally graded cemented carbides by energy dispersive synchrotron X-ray diffraction. Int. J. Refract. Met. Hard Mater. 2016, 56, 27-34. [CrossRef]

11. Stylianou, R.; Velic, D.; Daves, W.; Ecker, W.; Stark, A.; Schell, N.; Tkadletz, M.; Schalk, N.; Czettl, C.; Mitterer, C. Stress relaxation through thermal crack formation in CVD TiCN coatings grown on WC-Co with different Co contents. Int. J. Ref. Met. Hard Mater. 2020, 86, 105012. [CrossRef]

12. Gruber, D.P.; Kiefer, D.; Rössler, R.; Beckmann, F.; Tkadletz, M.; Klünsner, T.; Czettl, C.; Keckes, J.; Gibmeier, J. 20 Hz synchrotron Z-ray diffraction analysis in laser-pulsed WC-Co hard metal reveals oscillatory stresses and reversible composite plastification. Int. J. Ref. Met. Hard Mater. 2019, 82, 121-128. [CrossRef]

13. García, J.; Moreno, M.; Wan, W.; Apel, D.; Pinto, H.; Meixner, M.; Klaus, M.; Genzel, C. In Situ Investigations on Stress and Microstructure Evolution in Polycrystalline $\mathrm{Ti}(\mathrm{C}, \mathrm{N}) / \alpha-\mathrm{Al}_{2} \mathrm{O}_{3} \mathrm{CVD}$ Coatings under Thermal Cycling Loads. Crystals 2021, 11, 158. [CrossRef]

14. Friedrich, C.; Berg, G.; Broszeit, E.; Berger, C. Datensammlung zu Hartstoffeigenschaften. Mater. Werkst. 1997, 28, 59-76. [CrossRef]

15. Ruppi, S.; Larsson, A.; Flink, A. Nanoindentation hardness, texture and microstructure of $\alpha-\mathrm{Al}_{2} \mathrm{O}_{3}$ and $\mathrm{k}-\mathrm{Al}_{2} \mathrm{O}_{3}$ coatings. Thin Solid Film. 2008, 516, 5959-5966. [CrossRef]

16. Wachtman, J.B.; Scuderi, T.G.; Cleek, G.W. Linear thermal expansion of aluminium oxide. J. Am. Ceram. Soc. 1961, 10, 319-323.

17. Genzel, C.; Denks, I.A.; Gibmeier, J.; Klaus, M.; Wagener, G. The materials science synchrotron beamline EDDI for energydispersive diffraction analysis. Nucl. Instrum. Methods Phys. Res. Sect. Accel. Spectrometers Detect. Assoc. Equip. 2007, $578,23-33$. [CrossRef]

18. Noyan, I.C.; Huang, T.C.; York, B.R. Residual stress/strain analysis in thin films by X-ray diffraction. Crit. Rev. Solid State Mater Sci. 1995, 20, 125-177. [CrossRef]

19. Macherauch, E.; Müller, P. Das $\sin ^{2} \Psi$ —erfahren der röntgenographischen Spannungsmessung. Z. Angew. Physik. 1961, 113, 305-312.

20. Eshelby, J.D. The determination of the elastic field of an ellipsoidal inclusion, and related problems. Proc. R. Soc. Lond. Ser. Math. Phys. Sci. 1657, 241, 376-396.

21. Kröner, E. Berechnung der elastischen Konstanten des Vielkristalls aus den Konstanten des Einkristalls. Eur. Phys. J. A 1958, 151, 504-518. [CrossRef]

22. Gao, C.; Zhao, Z.; Li, X. Modeling of thermal stresses in elastic multilayer coating systems. J. Appl. Phys. 2015, 117, 055305. [CrossRef]

23. Azhari, I.; García, J.; Zamanzade, M.; Soldera, F.; Pauly, C.; Llanes, L.; Mücklich, F. Investigations on mi-cro-mechanical properties of polycrystalline $\mathrm{Ti}(\mathrm{C}, \mathrm{N})$ and $\mathrm{Zr}(\mathrm{C}, \mathrm{N})$ coatings. Acta Mat. 2018, 149, 364-376. [CrossRef]

24. García, J.; Moreno, M.; Östby, J.; Persson, J.; Pinto, H. Design of coated cemented carbide with improved comb crack resistance. In Proceedings of the 19th Plansee Seminar, Reutte, Austria, 29 May-2 June 2017.

25. Nemetz, A.W.; Daves, W.; Klünsner, T.; Ecker, W.; Teppernegg, T.; Czettl, C.; Krajinović, I. FE temperature- and residual stress prediction in milling inserts and correlation with experimentally observed damage mechanisms. J. Mater. Process. Technol. 2018, 256, 98-108. [CrossRef]

26. Mari, D.; Gonseth, D. A new look at carbide tool life. Wear 1993, 165, 9-17. [CrossRef]

27. El Azhari, I.; García, J.; Soldera, F.; Suarez, S.; Jiménez-Piqué, E.; Mücklich, F.; Llanes, L. Contact damage investigation of CVD carbonitride hard coatings deposited on cemented carbides. Int. J. Refract. Met. Hard Mater. 2020, 86, 105050. [CrossRef]

28. Klaus, M.; Genzel, C.; Holzschuh, H. Residual stress depth profiling in complex hard coating systems by X-ray diffraction. Thin Solid Film. 2008, 517, 1172-1176. [CrossRef] 
29. Ruppi, S. Enhanced performance of $\alpha-\mathrm{Al}_{2} \mathrm{O}_{3}$ coatings by control of crystal orientation. Surf. Coat. Technol. 2008, 202, 4257-4269. [CrossRef]

30. Measurement and modeling of temperature fluctuations in milling operations. Procedia CIRP 2016, 46, 173-176. [CrossRef]

31. El Azhari, I.; García, J.; Zamanzade, M.; Soldera, F.; Pauly, C.; Motz, C.; Llanes, L.; Mücklich, F. Micromechanical investigations of CVD coated WC-Co cemented carbide by micropillar compression. Mater. Des. 2020, 186, 108283. [CrossRef]

32. Kiani, S.; Ratsch, C.; Minor, A.; Kodambaka, S.; Yang, J.-M. Orientation- and size-dependent room-temperature plasticity in ZrC crystals. Philos. Mag. 2015, 95, 985-997. [CrossRef]

33. Sangiovanni, D.; Tasnádi, F.; Harrington, T.; Odén, M.; Vecchio, K.; Abrikosov, I. Temperature-dependent elastic properties of binary and multicomponent high-entropy refractory carbides. Mater. Des. 2021, 204, 109634. [CrossRef]

34. Chang, Y.H.R.; Yoon, T.L. Effects of nitrogen addition and growth condition on the enhanced mechanical properties of transition metal carbides TMC (TM = Zr, Hf). Ceram. Int. 2020, 46, 1124-1136. [CrossRef]

35. El Azhari, I.; Barrirero, J.; García, J.; Soldera, F.; Llanes, L.; Mücklich, F. Atom Probe Tomography investigations on grain boundary segregation in polycrystalline $\operatorname{Ti}(\mathrm{C}, \mathrm{N})$ and $\mathrm{Zr}(\mathrm{C}, \mathrm{N})$ CVD coatings. Scr. Mater. 2019, 162, 335-340. [CrossRef] 